\title{
Determination of Epidemiology and Seasonal Distribution of Viral Agents Detected in Children with Respiratory Tract Infection
}

\author{
Solunum Yolu Enfeksiyonlu Çocuklarda Saptanan Viral Etkenlerin \\ Epidemiyolojisi ve Mevsim Dağılımının Belirlenmesi
}

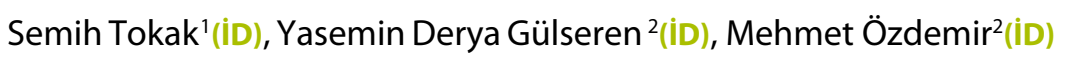 \\ ${ }^{1}$ Department of Medical Microbiology, KTO Karatay University School of Medicine, Konya, Turkey \\ 2 Division of Medical Virology, Department of Medical Microbiology, Necmettin Erbakan University School of Meram Medicine, Konya, Turkey
}

\begin{abstract}
Cite this article as: Tokak S, Gülseren YD, Özdemir M. Determination of epidemiology and seasonal distribution of viral agents detected in children with respiratory tract
\end{abstract} infection. J Pediatr Inf 2019;13(4):e158-e164.

\begin{abstract}
Objective: The aim of this study was to determine the viral pathogens in the respiratory tract infections of children who applied to various outpatient clinics of our hospital and to investigate their seasonal distribution.

Material and Methods: Between January 2016 and January 2017, 997 children $(45.1 \%$ female, $54.9 \%$ male, 0 month- 17 years) who were diagnosed with upper or lower respiratory tract infection were included in the study. Twenty-one viral respiratory pathogens were analyzed by multiplex polymerase chain reaction method by using Fast Track FTD kit (Fast Track Diagnosis, Luxemburg).

Results: One or more respiratory viruses were detected in 761 (76.3\%) of 997 patients and no virus was detected in 236 (22.8\%) of the patients. In our study, distrubition of respiratory tract viruses were as; Adenovirus (2.76\%), Bocavirus (4.20\%), Coronavirus 229E (0.92\%), Coronavirus OC43 (6.96\%), Enterovirus (6.04\%), Metapneumovirus A (4.60\%), Metapneumovirus B (4.47\%), Parainfluenza 1 (0.13\%), Parainfluenza 2 (1.18\%), Parainfluenza 3 (8.80\%), Parainfluenza 4 (1.18\%), Parainfluenza 4a (0.13\%), Parainfluenza 4b (0.13\%), Rhinovirus (48.75\%), RSVA/B (37.84\%), Influenza B (3.02\%) and Parechovirus (6.57\%). When we observe the seasonal distribution of viral agents, RSV was the most common agent in winter and it was rhinovirus in spring, summer and autumn season.
\end{abstract}

Conclusion: Approximately $80 \%$ of the patients included in the study had a viral agent that may be responsible for clinical symptoms. For this reason, the rapid and sensitive diagnosis of viruses causing viral respirato-

\section{Öz}

Giriş: Bu çalışmada hastanemizin çeşitli klinik ve polikliniklerine başvuran çocuk hastaların solunum yolu enfeksiyonlarında viral patojenlerin saptanması ve mevsimsel dağılımının araştırılması amaçlanmıştır.

Gereç ve Yöntemler: Bu çalışmaya, Ocak 2016-Ocak 2017 tarihleri arasında, üst veya alt solunum yolu enfeksiyonu ön tanısı alan, belirtileri ile hastaneye başvuran 997 çocuk (\%45.1 kadın, \%54.9 erkek, yaş aralığı 0 ay-17 yaş) dahil edildi. Hastalardan alınan örneklerden 21 viral solunum patojeni, Fast Track FTD Respiratory pathogens 21 (Fast Track Diagnosis, Luxemburg) kiti kullanılarak multipleks polimeraz zincir reaksiyonu yöntemi ile araştırıldı.

Bulgular: Toplam 997 hastanın, 761 (\%76.3)'inde bir veya birden fazla solunum virüsü saptanmış olup hastaların 236 (\%22.8)'sında virüs saptanmamıştır. Çalışmamızda solunum yolu virüslerinin dağılımı; Adenovirüs (\%2.76), Bokavirüs (\%4.20), Koronavirüs 229E (\%0.92), Koronavirüs OC43 (\%6.96), Enterovirüs (\%6.04), Metapnömovirüs A (\%4.60), Metapnömovirüs B (\%4.47), Parainfluenza 1 (\%0.13), Parainfluenza 2 (\%1.18), Parainfluenza 3 (\%8.80), Parainfluenza 4 (\%1.12), Parainfluenza 4a (\%0.13), Parainfluenza 4b (\%0.13), Rinovirüs (\%48.75), RSV A/B (\%37.84), İnfluenza B (\%3.02), Parekovirüs (\%6.57) şeklindedir. Etkenlerin mevsimsel dağılımına baktığımızda kış mevsiminde en sık rastlanılan etken RSV, ilkbahar, yaz ve sonbahar mevsiminde ise rinovirüs olmuştur.

\section{Correspondence Address/Yazışma Adresi \\ Semih Tokak \\ KTO Karatay Üniversitesi Tıp Fakültesi, \\ Tıbbi Mikrobiyoloji Anabilim Dalı, Konya-Türkiye \\ E-mail: semihtokak@gmail.com}

Received: 29.04 .2019
OCopyright 2019 by Pediatric Infectious Diseases and Immunization Society. Available online at www.cocukenfeksiyon.org 
ry infections will reduce the cost of treatment, reduce unnecessary use of antibiotics and prevent the development of resistance to antibiotics and will guide the clinician to prevent the infections caused by these viruses.

Keywords: Respiratory tract infections, multiplex polymerase chain reaction, seasonal distribution

\section{Introduction}

Respiratory tract infections (RTI) are significant public health problems in both developing and developed countries and lead to approximately $19 \%$ of all mortality among children under five years of age and to $8.2 \%$ of all disability and premature deaths (1). Along with the fact that bacteria and fungi cause respiratory tract infections, viruses are responsible of $40 \%-50 \%$ of the infections in babies and children admitted to hospitals for pneumonia in developing countries (2). Most commonly detected viruses among children with RTI include respiratory syncytial virus (RSV), influenza virus A (INF $A)$, influenza virus $B$ (INF $B$ ), parainfluenza viruses (PIV) and adenoviruses (AV) $(3,4)$. Acute respiratory tract infections are generally classified as upper respiratory tract infections (URTI) and lower respiratory tract infection (LRTI) according to their localizations (5). Most respiratory tract infections in the early childhood period are limited to upper respiratory tract. Lower respiratory tract infections develop in one third of the babies (6). It is reported that global acute respiratory tract infections make up of $40 \%$ of deaths in Bangladesh, India, Indonesia and Nepal. Viral co-infections occur in $4-33 \%$ of the children admitted to hospital for acute respiratory tract infections, and studies have reported that they are an increasing risk for clinical results $(7,8)$. The distribution of respiratory tract viruses leading to acute RTI varies according to population, climate and socioeconomic conditions $(9,10)$. The most important disease group for which inappropriate antibiotics are used is the viral upper RTI. Raising awareness of the public and physicians is extremely important to prevent and treat these infections. Vaccines are also available for some viruses. This study aimed to determine the prevalence, age distribution and seasonal changes of the respiratory tract viruses seen in patients aged 17 and under who referred to various clinics of our hospital.

\section{Materials and Methods}

This retrospective study investigated the respiratory tract samples of a total of 997 pediatric patients aged between 0 months and 17 years who had received a preliminary diagnosis of lower or upper RTI between January 2016 and January 2017 in the clinics and outpatient clinics of pediatric health and diseases department of a tertiary hospital in Konya. The
Sonuç: Çalışmaya dahil edilen hastaların yaklaşık \%80'inde klinik belirtilerden sorumlu olabilecek bir viral etken saptanmıştır. Bu nedenle viral solunum yolu enfeksiyonlarına neden olan virüslerin hızlı ve duyarlı tanısı tedavi maliyetini düşürecek, gereksiz antibiyotik kullanımını azaltacak ve antibiyotiklere direnç gelişimini engelleyecek ayrıca bu virüslerin neden olabilecekleri hastane enfeksiyonlarının önlenebilmesi açısından klinisyene yol gösterici olacaktır.

Anahtar Kelimeler: Solunum yolu enfeksiyonları, multipleks polimeraz zincir reaksiyonu, mevsimsel dağılım

patients included into the study were diagnosed with URTI, acute bronchitis, bronchiolitis, bronchopneumonia and pneumonia by having evaluated disease symptoms, physical examination findings and radiological data together. The nasopharyngeal swab samples of these patients taken with dacron swab were transported to the laboratory inside viral transport media [Universal transport medium (UTM), kit, Copan Diagnostics, Brescia, Italy] in a few hours following the cold chain rules and were kept in $-80^{\circ} \mathrm{C}$ until laboratory tests were performed.

Extraction of nucleic acids were performed using Qiagen EZ1 Virus Mini Kit v2.0 (Qiagen, Hilden, Germany) from the samples obtained in the study. Twenty-one viruses obtained from the samples of the patients were Adenovirus (AV), Human Bocavirus (HBoV), Coronavirus 229E (HCoV-229e), Coronavirus OC43 (HCoV-OC43), Enterovirus (EV), Human metapneumovirus A/B, Influenza A, Influenza A (H1N1), Influenza B, Parainfluenza 1, Parainfluenza 2, Parainfluenza 3, Parainfluenza 4, Parainfluenza 4, Parechovirus (HPeV), Respiratory syncytial virus A/B (RSV), Rhinovirus (RV), Seasonal (H1N1/H3N2). The kit is a ready-to-use set containing primers detecting each virus and TaqMan probes. Since viral nucleic acid is RNA, a reverse transcription was carried out in order to generate CDNA before real-time PCR. Afterwards, CDNA was multiplied with real-time PCR using specific primary/probe concordance, and amplicons were detected by measuring fluorescent radiation during PCR reaction.

Fluorescent radiation was measured with $A B I 7500$ system in the detection of amplicons. In the test, sample results in which fluorophore ( FAM ), fluorescent signal was obtained were accepted positive. In the sample, the test was accepted negative if fluorescent was present in internal control and positive and negative controls resulted accurately in the absence of FAM fluorescent signal. In the sample, the test was considered invalid and was re-run if there was no fluorescent in the internal control and/or positive controls.

SPSS Windows version 21 (Armonk, NY: IBM Corp.) was used for the statistical analyses of data. Descriptive statistics and Chi-square test were used to evaluate differences in terms of gender and age groups. Statistical significance was set at $p$ value $<0.05$. This study was approved by the Non-Pharmaceu- 
ticals and Non-Medical Devices Research Ethics Committee of KTO Karatay University Medical School (41901325-050.99, 21.02.2019)

\section{Results}

Between January 2016 and January 2017, 997 children (45.1\% female, $54.9 \%$ male, 0 month-17 years) who were diagnosed with upper or lower RTI were included into the study. The study included 480 outpatients and 517 inpatients. Demographics of our study group is given in Table 1.

\section{Prevalence of Respiratory Tract Viruses}

When the samples taken from the patients were examined, $\mathrm{RV}$ was determined to be the predominant agent among the viruses investigated, seen in 371 (37.21\%) of the 997 patients included into the study. It comprised $48.75 \%$ of the respirato-

Table 1. Demographics of the patients

\begin{tabular}{|l|c|}
\hline Patient demographics & Number \\
\hline $\begin{array}{l}\text { Gender } \\
\text { Female }\end{array}$ & $450(45.1 \%)$ \\
Male & $547(54.9 \%)$ \\
\hline Age & \\
$0-12$ months & $525(52.7 \%)$ \\
$13-36$ months & $194(19.4 \%)$ \\
37 months $>$ & $278(27.9 \%)$ \\
\hline Outpatient & $480(48.1 \%)$ \\
\hline Inpatient & $517(51.9 \%)$ \\
\hline Patients in whom viral agent is detected & $761(76.3 \%)$ \\
\hline & \\
\hline
\end{tabular}

ry tract positive patients. RV was followed by RSV among the respiratory tract viruses detected. Coinfection of three viruses was confirmed in 13 patients and coinfection of four viruses was determined in three. RSV and RV were the most commonly found agents in these coinfections and were more frequently encountered in children aged 0-12 months. Moreover, a statistically significant difference was not found between the detected viruses and gender. Virus distribution according to gender is given in Figure 1.

\section{The Relation Between Respiratory Tract Viruses and Age}

The highest detection rate for viral respiratory pathogens was in the $0-12$-month group $(423 / 525 ; 80.42 \%)$ then in the 12-36-month and 37-month and over group as 153/194; $78.86 \%$ and 185/278; 66.78\%, respectively. RSV and RV were the most commonly encountered respiratory tract viruses in all age groups. Distribution of various viral agents in all age groups is given in Figure 2.

\section{Seasonal Distribution of Respiratory Tract Viruses}

Seven hundred and sixty-one viruses were detected from the samples obtained from 997 patients between January 2016 and January 2017 (76.3\%). Viruses were detected in all seasons during the study period, but the highest detection rate was in winter (Figure 3). The most commonly seen respiratory tract virus was RV. In addition, seasonal change of each respiratory virus was analyzed in this study. Considering the seasonal distribution of the agents, the most commonly encountered agent in winter was RSV and that encountered in summer and autumn was RV (Figure 3 ).

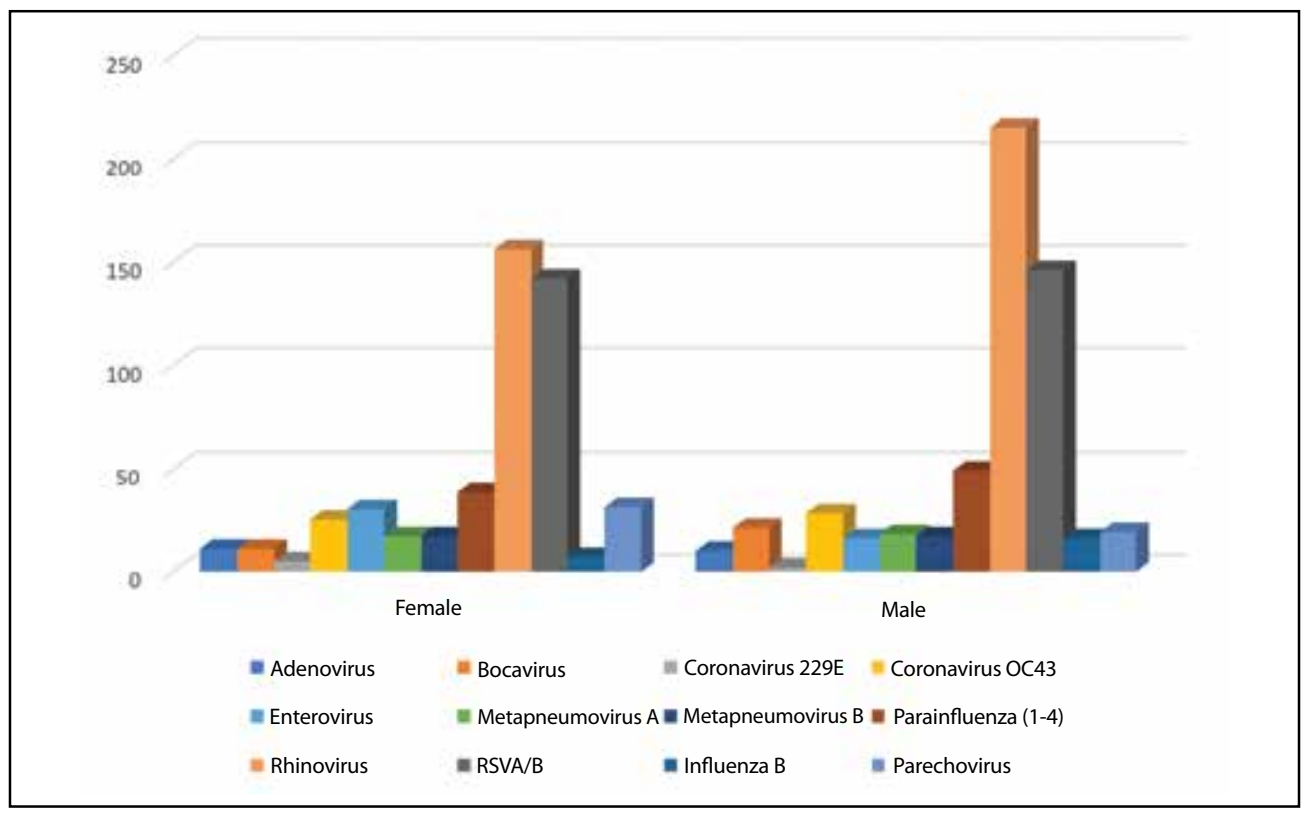

Figure 1. Gender distribution of respiratory tract viruses. 


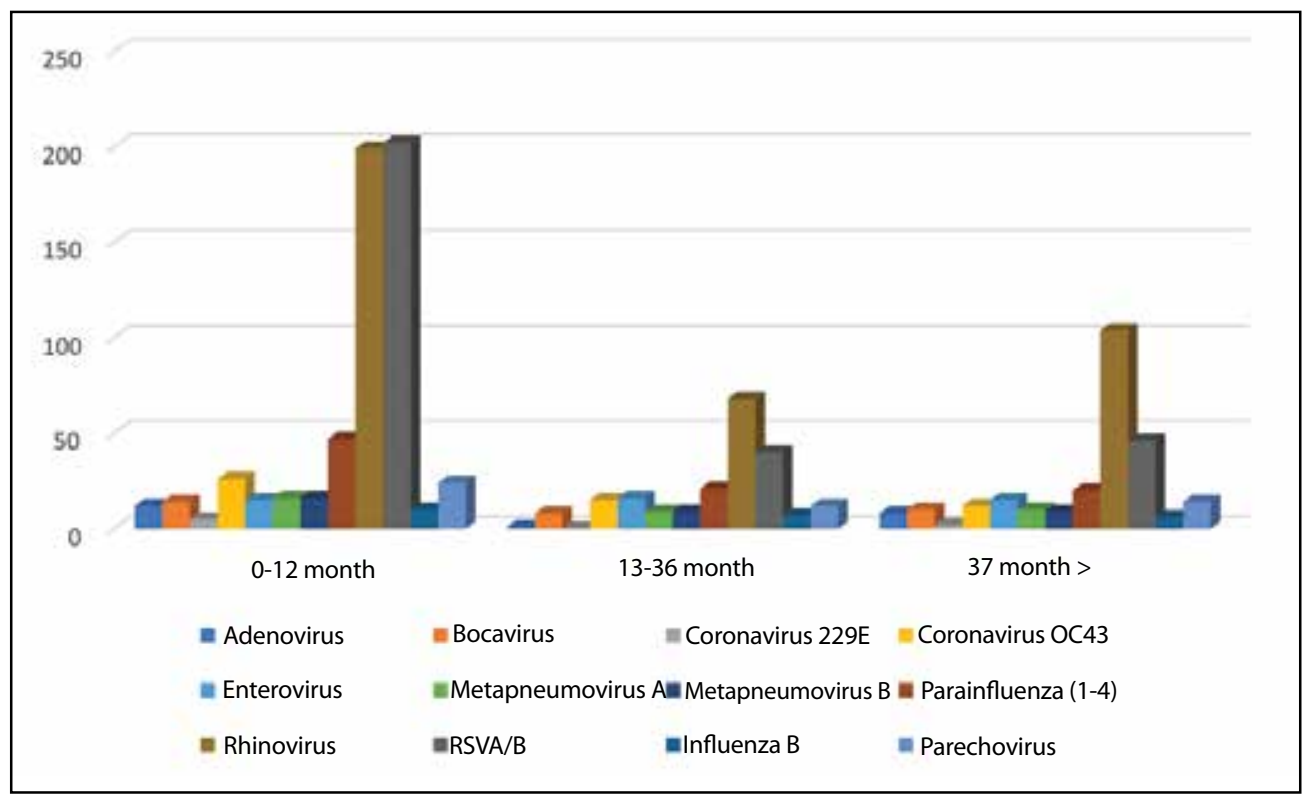

Figure 2. Age-related distribution of the viruses in respiratory tract positive patients.

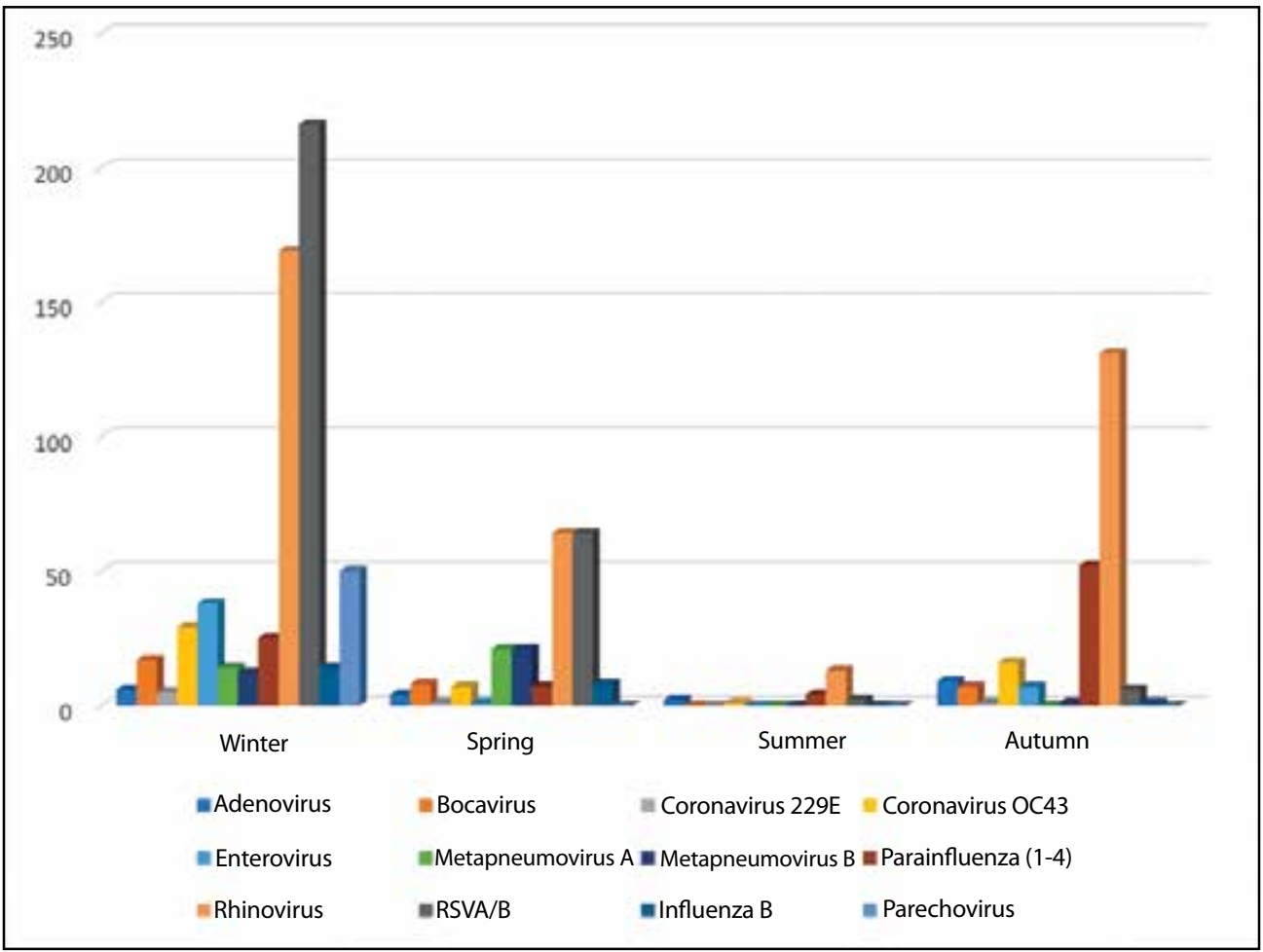

Figure 3. Seasonal distribution of respiratory tract viruses.

\section{Discussion}

Acute respiratory tract infections are responsible for about 3.9 million deaths in young children worldwide annually. The reason why prevalence of pneumonia has increased in developing countries is malnutrition, low birth weight and indoor air pollution (11). Detection rate of viral agents in RTI seen in developing countries has been reported as $14-48 \%(12,13)$. Therefore, the determination of the prevalence of respiratory viruses carry importance for the prevention, control and treatment of RTI especially in seasons when an increase is encountered. Our study aimed determining the epidemiology and seasonality of respiratory tract viruses in the pediatric population between January 2016 and January 2017. 
After the year 2000, five new viruses notably HMPV, HBoV, NL63 of HCoV, HKU1 and SARS-CoV serotypes were added to the agents previously known as respiratory viruses like parainfluenza viruses INF-A, INF-B, ADV and RSV. Furthermore, epidemics with new serotypes of INF-A, namely H5N1 (bird flu) and H1N1 (swine flu), have been encountered (14). In this study, respiratory viruses were detected in 761 of the 997 inpatients and outpatients (76.3\%) who applied to hospital with the complaint of acute upper or lower respiratory tract. In comparison to other studies, positivity rate of the respiratory viruses has been found between $34.4 \%$ and $67.8 \%$ in the studies conducted in Turkey (14). In studies abroad, respiratory viruses have been found positive at a rate of $36.5 \%$ in America, $32 \%$ in Southeastern Asia and about $43 \%$ in Europe in patients with acute RTI (14). Positivity rate obtained in our study shows similarity with previous studies. Additionally, multiple agent infections (coinfections with two, three, four agents) were confirmed in $27 \%$ of the patients. This result that we obtained showed similarity with a previous study (10\%-43.5\%) (15).

$\mathrm{RV}$ was the most frequently identified pathogen in summer and autumn seasons in the 13-36 month and 37 month and over age groups (48.75\%). Rhinoviruses are reported as the most commonly detected agents in different regions of the world. In a study conducted in the USA using a commercial multiplex nucleic acid amplification test has been found positive in $66 \%$ of the samples taken from pediatric patients. RV was detected as the agent causing respiratory tract infection between January 2014 and January 2015. Moreover, it has been observed that $\mathrm{RV}$ reached its highest level in spring and autumn all year long $(16,17)$. A study including mainly pediatric patients in Korea has reported that RV was the number one etiological factor (18).

In our study, RSV A/B (37.84\%) was detected as the second most frequently detected agent after RV. It was seen that it reached its highest level especially in winter and spring. Do et al. have found $72 \%$ of the samples collected from 309 children positive with multiplex PCR method in the Netherlands and detected RSV as the most common agent in 73 samples (24\%) (19). Again, in Brazil in another study conducted with the same method in 407 children, viral pathogen was detected in $85.5 \%$ of the samples and RSV was the most frequently detected agent with a rate of $37 \%$ (20). Similar to RSV, HMPV infections are frequently seen in winter and spring like in our study and $90 \%$ of the HMPV cases has been detected in January and April (21). INF A was not seen in our study. INF B, on the other hand, was detected at a rate of $3.02 \%$ and reached its highest level between January and March.

ADVs were detected in $21(2.76 \%)$ cases in autumn and winter seasons. Although seasonal features of adenoviral infections are affected by geographical regions and the genotype of the virus, the literature states that these kinds of in- fections are more frequently encountered in September and February $(22,23)$.

Parainfluenza virus is a major respiratory virus, has 4 subtypes and is the most frequent reason of croup and pneumonia in babies. PIV-1 is mostly associated with acute croup. PIV-2 is generally seen less than PIV-1 or PIV-3 and is mostly isolated from URTI. Although PIV-4 from the parainfluenza group has been known to be associated with mild URTI for years, recent studies have indicated that PIV-4 is an agent in severe LRTI especially in children (24). PIV3 was the most frequently detected subtype in our study, followed by PIV2, PIV4 and PIV1. PIV1 and PIV-2 reached their highest level in autumn and winter and PIV-3 generally reached its highest level in winter. In other studies, PIV3 has been reported as the most commonly seen subtype following PIVs similar to our study $(25,26)$.

Influenza cases usually result in a self-limiting illness in healthy, non-immunosuppressed individuals, but serious complications may occur in the elderly, children, and other risk groups (27). Influenza has become the center of attention among all respiratory viruses due to pandemia and annual epidemics and causes a seasonal disease seen generally in winter months between November and April in the Northern Hemisphere. In ours study, Influenza A was not observed but Influenza B was encountered between November and April.

Since its identification in 2005 , bocavirus has been isolated between $1.5 \%$ and $19 \%$ of the respiratory tract samples of children applying to hospitals due to respiratory tract viral disease $(28,29)$. Bocavirus causes coinfections in up to $90 \%$ of the cases along with other agents like influenza, rhinovirus, parainfluenza, RSV and metapneumoniavirus $(30,31)$. In our study, bocavirus prevalence was at a rate of $4.20 \%$ and was seen to cause coinfections mostly with Rhinovirus, RSV and HPeV.

Coronaviruses are commonly found in the world. The distributions of HCoV-OC43, HCoV-229E, HCoV-NL63 and HCoVHKU1 viruses in the world are different and the dominant type can change year after year (32). Though they generate infection in winter months in temperate climates, small epidemics can be sometimes be seen in spring months. Rhinovirus or RSV coinfection has been encountered in nearly half of coronaviruses. These infections have been detected in all months of the year except for June. It has been reported that coronavirus infections peaks mostly in winter months without a significant difference in seasonality or origin (obtained from community or hospital) between the four subtypes $(33,34)$. In conformity with previous studies, our study found that coronaviruses peak in winter months.

Enteroviruses lead to URTI and LRTI including pneumonia and bronchiolitis in both children and adults. Enteroviruses peak in late summer and autumn months and seen in winter in temperate climates. Jacques et al. (34) have conducted a research in 
between French children and reported that $47 \%$ of enterovirus infections occur in spring and autumn months $(35,36)$. In our study, nearly all enterovirus infections were detected in winter.

HPeVs are common pathogens infecting young children worldwide. HPeVs are seen to be transmitted by fecal-oral routes and most $\mathrm{HPeV}$ infections are responsible for mild respiratory tract infection and gastroenteritis. Although $\mathrm{HPeV}$ infections are generally seen all year long, they demonstrate a significant seasonal epidemiology. These infections reach peak worldwide in autumn and winter months (37). All HPeV in our study were detected in winter.

In conclusion, at least one respiratory tract virus was detected in a majority (76.3\%) of the patients applying to various pediatric clinics of our hospital with respiratory tract complaints. Our study put forward that viral pathogens are important causes of acute respiratory tract infections in our region. $\mathrm{RV}$ was the most common virus for all age groups during the study period, followed by RSV. The fact that multiplex PCR methods used are sensitive and specific and show results in a very short time is beneficial to patient management make us consider that they will be helpful in understanding thoroughly the virus distribution in our region, in contributing to the prevention of misuse of antibiotics and in implementing an effective prevention approach to each and every virus especially at times when they are most dominant.

Ethics Committe Approval: This study was approved by the NonPharmaceuticals and Non-Medical Devices Research Ethics Committee of KTO Karatay University Medical School (41901325-050.99, 21.02.2019).

Informed Consent: Patient concent was obtained.

Peer-review: Externally peer-reviewed.

Author Contributions: Concept - ST; Design - ST, YDG; Supervision - MÖ; Data Collection and/or Processing - ST, YDG; Analysis and/or Interpretation - ST, YDG, MÖ; Literature Review - ST, YDG; Writing - ST, YDG, MÖ; Critical Review - All of authors.

Conflict of Interest: No conflict of interest was declared by the authors.

Financial Disclosure: The authors declared that this study has received no financial support.

\section{References}

1. Shi T, McLean K, Campbell H, Nair H. Aetiological role of common respiratory viruses in acute lower respiratory infections in children under five years: a systematic review and meta-analysis. J Glob Health 2015;5:010408. [CrossRef]"

2. Simoes EAF, Cherian T, Chow J, Shahid-Salles SA, Laxminarayan R, John $T J$. Acute respiratory infections in children. In: Jamison DT, Breman JG, Measham AR (eds). Disease Control Priorities in Developing Countries. 2nd ed. Chapter 25. Washington (DC): World Bank, 2006.
3. Doan $Q$, Enarson P, Kissoon N, Klassen TP, Johnson DW. Rapid viral diagnosis for acute febrile respiratory illness in children in the emergency department. Cochrane Database Syst Rev 2014;15:CD006452. [CrossRef]

4. Sung RY, Chan PK, Tsen T, Li AM, Lam WY, Yeung AC, et al. Identification of viral and atypical bacterial pathogens in children hospitalized with acute respiratory infections in Hong Kong by multiplex PCR assays. J Med Virol 2009;8:153-9. [CrossRef]"

5. Williams BG, Gouws E, Boschi-Pinto C, Bryce J, Dye C. Estimates of worldwide distribution of child deaths from acute respiratory infections. Lancet Infect Dis 2002;2:25-32. [CrossRef]"

6. Tregoning JS, Schwarze J. Respiratory viral infections in infants: causes, clinical symptoms, virology, and immunology. Clin Microbiol Rev 2010;23:74-98. [CrossRef]"

7. Sikolia DN, Mwololo K, Cherop H, Hussein, Juma M, Kurui J, Bwika A, et al. The prevalence of acute respiratory tract infections and the associated risk factors: $A$ study of children under five years of age in Kibera Lindi Village, Nairobi, Kenya. J Natl Inst Public Health 2002;51:67-72. [CrossRef]

8. WHO. World Health Report 2004, Report of The Director General. Geneva: WHO, 2004

9. Perezruiz $M$, Pedrosacorral I, Sanbonmatsugamez S, Navarromari J. Laboratory detection of respiratory viruses by automated techniques. Open Virol J 2012;6:151-9. [CrossRef],

10. Noh JY, Song JY, Cheong HJ, Choi WS, Lee J, Lee JS, et al. Laboratory surveillance of influenza-like illness in seven teaching hospitals, South Korea: 2011-2012 season. PLoS One 2013;8:e64295. [CrossRef],

11. WHO, regional office of SEAR. Health Situation in the South East Asia Region monograph, 1994-1997. New Delhi: WHO, 1999.

12. Bharaj P, Sullender WM, Kabra SK, Mani K, Cherian J, Tyagi V, et al. Respiratory viral infections detected by multiplex $P C R$ among pediatric $p a-$ tients with lower respiratory tract infections seen_at an urban hospital in Delhi from 2005 to 2007. Virol J 2009;6:89. [CrossRef].

13. Bukhari EE, Elhazmi MM. Viral agents causing acute lower respiratory tract infections in hospitalized children at a tertiary care center in Saudi Arabia. Saudi Med J 2013;34:1151-5. [CrossRef]

14. Çiçek C, Arslan A, Saz EU, Pullukçu H, Çok G. Üst ve alt solunum yolu enfeksiyonu olan hastalarda solunum virüslerinin multipleks $P C R$ yöntemi ile eşzamanlı saptanması. Ege Tıp Dergisi 2015;54:8-14."[CrossRef]

15. Aktürk H, Sütçü $M$, Badur $M$, Törün $S H$, Çıtak A, Erol OB, et al. Evaluation of epidemiological and clinical features of influenza and other respiratory viruses. Turk Pediatri Ars 2015;50:217-25. [CrossRef]"

16. Arbefeville S, Ferrieri P. Epidemiologic analysis of respiratory viral infections mainly in hospitalized children and adults in Midwest University Medical Center after the implementation of a 14-virus multiplex nucleic acid amplification test. Am J Clin Pathol 2017;147:43-9. [CrossRef]

17. Nickbakhsh S, Thorburn F, Von Wissmann B, McMenamin J, Gunson $R N$, Murcia PR. Extensive multiplex PCR diagnostics reveal new insights into the epidemiology of viral respiratory infections. Epidemiol Infect 2016;144:2064-76. [CrossRef]"

18. Ko DH, Hyun J, Kim HS, Kim JS, Song W, Kim HS. Analysis of respiratory viral infections detected using multiplex real-time PCR in Hwaseong, Korea from 2013 to 2015. Clin Lab 2017;63:1003-7. '[CrossRef]'

19. Do $A H$, van Doorn HR, Nghiem MN, Bryant JE, Hoang TH, Do QH. Viral etiologies of acute respiratory infections among hospitalized Vietnamese children in Ho Chi Minh City, 2004-2008. PLoS One 2011;6:e18176. [CrossRef],

20. Bezerra PG, Britto MC, Correia JB, Duarte Mdo C, Fonceca AM, Rose K, et al. Viral and atypical bacterial detection in acute respiratory infection in children under five years. PLoS One 2011;6:e18928. [CrossRef].

21. Haynes AK, Fowlkes AL, Schneider E, Mutuc JD, Armstrong GL, Gerber SI. Human metapneumovirus circulation in the United States, 2008 to 2014. Pediatrics 2016;137(5). [CrossRef] 
Tokak et al.

22. Erdman DD, Xu W, Gerber SI, Gray GC, Schnurr D, Kajon AE. Molecular epidemiology of adenovirus type_7_ in the United States, 1966-2000. Emerg Infect Dis 2002;8:269-77. '[CrossRef]"

23. Cheng CC, Huang LM, Kao CL, Lee PI, Chen JM, Lu CY, et al. Molecular and clinical characteristics of adenoviral infections in Taiwanese children in 2004-2005. Eur J Pediatr 2008; 167:633-40!' [CrossRef]",

24. Ren L, Gonzalez R, Xie Z, Xiong Z, Liu C, Xiang Z, et al. Human parainfluenza virus type 4 infection in Chinese children with lower respiratory tract infections: a comparison study. J Clin Virol 2011;51:209-12. "[CrossRef]"

25. Fy AM, Curns AT, Harbour K, Hutwagner L, Holman RC, Anderson LJ. Seasonal trends of human parainfluenza viral infections: United States, 1990-2004. Clin Infect Dis 2006;43(8):1016-22. [CrossRef].

26. Zhao H, Harris RJ, Ellis J, Donati M, Pebody RG. Epidemiology of parainfluenza infection in England and Wales, 1998-2013: any evidence of change? Epidemiol Infect 2017;145(6):1210-20. [CrossRef].

27. Özdemir M, Taşbent FE. New index of journal and influenza viruses. $J$ Pediatr Infect Dis 2018;13(01):001. [CrossRef],

28. Allander T. Human bocavirus. J Clin Virol 2008;41:29-33."[CrossRef]"

29. Martin ET, Fairchok MP, Kuypers J, Magaret A, Zerr DM, Wald A, et al. Frequent and prolonged shedding of bocavirus in young children attending daycare. J Infect Dis 2010;201:1625-32!"[CrossRef]"

30. Moreno B, Abrego L, Carrera JP, Franco D, Gaitán M, Castillo J, et al. Detection of human bocavirus type 1 infection in Panamanian children with respiratory illness. J Med Virol 2016;88:389-94. [CrossRef].
31. Gaunt ER, Hardie A, Claas EC, Simmonds P, Templeton KE. Epidemiology and clinical presentations of the four human coronaviruses $229 E$, HKU1, NL63, and OC43 detected over 3 years using a novel multiplex real-time PCR method. J Clin Microbiol 2010;48:2940-7. [CrossRef]"

32. Varghese L, Zachariah P, Vargas C, LaRussa P, Demmer RT, Furuya YE, et al. Epidemiology and clinical features of human coronaviruses in the pediatric population. J Pediatric Infect Dis Soc 2018;7:151-8. [CrossRef]"

33. Litwin CM, Bosley JG. Seasonality and prevalence of respiratory pathogens detected by multiplex $P$ CR at a tertiary care medical center. Arch Virol 2014;159:65-72. [CrossRef].

34. Andréoletti L, Renois F, Jacques J, Lévêque N. Human enteroviruses and respiratory infections. Med Sci (Paris) 2009; 25:921-30. [CrossRef].

35. Harvala $H$, Simmonds $P$. Human parechoviruses: biology epidemiology $_{\perp}$ and clinical significance. J Clin Virol 2009;45:1-9!'[CrossRef]"

36. Jacques J, Moret H, Minette D, Lévêque N, Jovenin N, Deslée G, et al. Epidemiological, molecular, and clinical features of enterovirus respiratory infections in French children between 1999 and 2005. J Clin Microbiol 2008;46:206-13. [CrossRef]"

37. Siafakas N, Markoulatos P, Levidiotou-Stefanou S. Molecular identification of enteroviruses responsible for an outbreak of aseptic meningitis; implications in clinical practice and epidemiology. Mol Cell Probes 2004;18:389-98. [CrossRef] 